\title{
ERDŐS ÁKOS
}

\section{A rendészeti elsősegélynyújtás alapjai: definíciók, funkciók, célok}

\begin{abstract}
„Ha »életröl « beszélünk, meg kell mondanunk, hogy mit is értünk rajta, mert mást-mást ért életen a természettudós, a filozófus és a költö. Ez az emberi gondolkozás három fö típusa, és ugyanazt a dolgot mindegyikük másképp látja és máképp közeliti meg. A természettudomány és a természettudós lényegében csak mér, és igyekszik különbözö méréseinek eredményeit közös nevezöre hozni. Ami grammal, méterrel vagy másodperccel nem mérhetö, azt nem veszi figyelembe. A filozófus megfigyeléseit gondolkozó apparátusával próbálja megérteni, míg a költö egyetlen realitásnak belsö élményét tekinti. Egyformán jogosult mind a három nézöpont vagy módszer. Egyénisége és mestersége szerint az egyes ember az egyik vagy a másik fajtához tartozik, de a határok nem élesek, mert minden igazi természettudósba szorult egy kis filozófus meg egy kis költö és fordítva" - fogalmazott az emberi kogníció és értelmezés sokszínüségének jelentőségére utalva, a Nobel-díjas magyar kutató, Szent-Györgyi Albert.

Dacára azonban az iménti és ahhoz hasonló intelmeknek, előfordul, hogy a különböző tudományos diszciplínák vagy szakterületek gyakorlati találkozásakor az őket rendszerező keretek oly mértékben képesek egymásnak feszülni, hogy az az adott probléma megoldása kapcsán, akarva-akaratlanul kizárólagos érdekérvényesító és véleményformáló joggal ruházza fel az egyik vagy másik szakmai, illetve tudományos nézőpontot.

Az effajta gyakorlati és intellektuális önzés az esetek többségében, nemcsak hogy kontraproduktív, de egyenesen káros.

Véleményem szerint, a közösséget érintő problémák megoldásában a tudománnyal és a különböző szakmai területekkel szemben támasztott mindenkori elvárásunk a hatékony együttmüködésre törekvés kell hogy legyen. S a kihívásokat támasztó helyzetek leküzdésében e diszciplínák és gyakorlati szakterületek egymást segítve, kiegészítve kell hogy helyt álljanak.

A rendészet gyakorlatában az előbbiekre vonatkoztatott egyik legkiválóbb példa a szolgálati feladatok ellátásakor felvetődő azonnali ellátást igénylő
\end{abstract}

1 Szent-Györgyi Albert: Az élő állapot. Kriterion Könyvkiadó, Bukarest, 1973, 11. o. 
egészségromlások, egészségügyi káresemények kezelésének a kérdése. Amikor a rendészeti feladat végrehajtásakor megjelenik az egészségügyi beavatkozás, az élet megóvásának és a szakszerű mentésnek az igénye. Az effajta feladatok - sajátosságuk révén - alapvetően a rendészet, valamint az orvosés egészségtudomány kompetenciahatárán elhelyezkedve várják a megoldást, ez szükségszerüvé teszi e két tudományterület elméleti és gyakorlati összedolgozását.

A mentésszervezés, az egészségügyi ellátás és a rendészet valamiféle öszszehangolásának igénye, számtalan gyakorlati példában jelentkezett már (például balesetekkel, büncselekményekkel érintett sértettek), s jelentkezik ma is. E „fehér folt” elfedésére ígéretes elképzelések és szakmai próbálkozások láttak már napvilágot, azonban mind ez idáig e probléma tudományos igényü értékelésére nem került sor.

E tanulmány célja, hogy a rendészet és az annak feladatellátásával kapcsolatban jelentkező egészségügyi beavatkozások azon szegmensét mutassa be, amely alapszintü elvárásként támaszható a rendészeti szakemberekkel szemben, s amelyek anélkül merítenek az orvos- és egészségtudomány ismeretanyagából, hogy az átvezetné őket e tudomány képzési területére.

Tehát egy olyan probléma tudományos vizsgálatát és értékelését tủztem ki célul, amit korábban még ilyen formában nem érintettek, s amely sajátosságainál fogva megköveteli a különböző tudományágak hatékony és egymást elismerö együttmüködését.

\section{Fogalmak tisztázása}

Tekintettel arra, hogy e témában mind ez idáig egyáltalán nem vagy csak korlátozott formában született tudományos igényű munka, szükségszerünek tartom a kapcsolódó és legfontosabb fogalmak tisztázását. Az olyanokét mint a rendészeti kárhely, a rendészeti elsősegélynyújtó vagy a rendészeti elsősegélynyújtás. E fogalmak segítenek ugyanis eligazodni és választ adni a speciális sérült- és betegellátás e formájának a hol? ki? és mit? tesz, illetve tehet kérdéseire.

Ahogy egy bünügy feltárása, az ,,igazság megtalálása” kapcsán, elengedhetetlen a kriminalisztika alapkérdéseinek megválaszolása ${ }^{2}$, úgy témánk vo-

\footnotetext{
2 Fenyvesi Csaba: A kriminalisztika alapkérdései. In: Gaál Gyula - Hautzinger Zoltán (szerk.): Tanulmányok „A változó rendészet aktuális kihívásai” című tudományos konferenciáról. Pécs, 2013, 341. o. [Pécsi Határör Tudományos Közlemények XIV.]
} 
natkozásában is szükséges a rendszer átláthatóságát és megértését célzó kérdésekre adott felelet.

\section{Rendészeti kárhely}

A téma szempontjából e sajátos szakkifejezés magyarázatát és egyértelmüsítését azért tartom elengedhetetlennek, mert a későbbiekben hivatkozott tevékenységeknek tulajdonképpen e fogalom szabja meg a speciális térbeli kereteit, s az abban intézkedésre kötelezettek és jogosultak körét.

A kárhely fogalma az élet- és vagyonmentés tudományos és gyakorlati szintü müvelöi körében gyakran használt kifejezés. Általában e fogalom, a rendészet mellett olyan tudomány- és szakterület által alkalmazott, mint az orvostudományi terület vagy a katasztrófavédelmi szakma. A rendészeti kárhely esetében tehát a rendészet mintegy specializálja a kárhely fogalmát.

A sürgősségi orvostanhoz (oxyológia) és prehospitális egészségügyi ellátáshoz kapcsolódó tudományos és jogalkotói szóhasználatban a kárhely a tömeges balesetekkel szorosan összefüggő fogalom. ${ }^{3}$ Ahogyan Seres Ambrusné fogalmaz: „, a balesetek helyszinét kárhelynek nevezzük, amely lehet dinamikus illetve statikus. Ez elöbbi esetben újabb és újabb sérültekre kell számitani (pl. járvány, terrortámadás), míg az utóbbinál a sérülések döntö többsége az elsö percekben kialakul (pl. közlekedési balesetek)."

Míg a katasztrófavédelem szakmai fogalomtárában a „kárhely, a tüzoltói beavatkozás során érintett terület, melynek határát az irányitásért felelös személy (a tüzoltásvezetö) jelöli ki"'.

A két értelmezés között a jelentős különbséget az adja, hogy míg az előbbi szükségszerüen számol a személyi sérülés bekövetkezésével, utóbbi esetében a testi épséget sértő tényleges káresemény megjelenése csupán eshetőleges. Mindazonáltal egységes a megközelítés a tekintetben, hogy a kárhely a fizikai térben egy az általánostól, megszokottól eltérő, valamilyen szempont alapján elkülöníthető területnek számít (például baleset, tüzkár helyszíne).

Az előbbiek figyelembevételével a rendészeti kárhely fogalmát a következők szerint javasolom megfogalmazni: egy olyan, az eljárni jogosult rendészeti szerv tagja által kijelölt és lezárt terület, ahol egészségügyi ellátásra, il-

3 Gőbl Gábor: Oxiológia. Medicina Könyvkiadó Zrt., Budapest, 2006; 1997. évi CLIV. törvény 94. § (5) bek.

4 Seres Ambrusné: Betegvizsgálat, a sérült állapotának értékelése, segélyhívás, a beteg szállítása. Nemzeti Szakképzési és Felnőttképzési Intézet, Budapest, 2008, 15. o.

5 5/2014. (II. 27.) BM OKF utasítás ért. rend. 4. pont 
letve mentésre szoruló személyek tartózkodhatnak, azonban ott továbbra is számítani kell olyan ellenséges emberi tevékenységre, amely a rendészeti szerv tagján kivül más személyek életét és testi épségét is veszélyeztetheti.

Más tudományos munkában a rendészeti kárhely fogalmát a következőképp definiálták: ,, a rendőrség által rendészeti tevékenység miatt lezárt terület, ahol mentésre illetve egészségügyi ellátásra szoruló személy vagy személyek tartózkod(hat)nak".

Bár az előbbiek általános lényegével egyetértek, a definiált fogalom megnevezése és annak leírása között értelmezési deficitet tapasztalok a rendőrség és rendészet kizárólagos azonosításában.

Ahogy azt korábban megjegyeztem, a rendészet specializálja a kárhely fogalmát, így ez előbbi pontos értelmezése elengedhetetlen. A rendészet, ahogy Finszter Géza fogalmaz: ,, a közigazgatásnak az a területe, amely a legitim fizikai eröszak-monopólium birtokában a jogellenes emberi magatartásoktól óvja a közrendet és a közbiztonságot"”.

Tehát a rendészeti tevékenység és a vele összefüggő fogalmak, így a rendészeti kárhely kapcsán is kijelenthető, hogy az ott eljárni, intézkedni jogosultak és kötelezettek körét a legitim erőszak alkalmazóinak, a rendészeti szervek hivatásos állományának tagjai adják. Hazánkban a legitim erőszak alkalmazóinak köre ugyanakkor jóval túlmutat a rendőrség állományán (például a Nemzeti Adó- és Vámhivatal vagy a büntetés-végrehajtási szervezet hivatásos állománya), ezáltal a rendészeti kárhely sem kizárólag a rendőrség tevékenységi tere. Ha megvizsgáljuk a Nemzeti Adó- és Vámhivatal rendészeti tevékenységeinek széles körét, így például a határon végzett feladatokat (bünüldözés, bünmegelőzés, felderítés és nyomozás, vám- és jövedéki ellenőrzés, örzésvédelem stb. $)^{8}$, láthatjuk, hogy bármikor szükségessé válhat a terület lezárása a definícióban említett esetek felvetődésekor. Az idézett meghatározásban foglaltakat inkább nevezném a rendörségi kárhely definíciójának.

Fontosnak tartom azt is megjegyezni, hogy a fentiekben használt ellenséges emberi magatartás kifejezés sem azonosítható kizárólag az aktív támadással. Eben az értelemben ellenséges emberi magatartásnak tekinthető minden olyan tevékenység, amely a rendészeti kárhely területén tartózkodók számára a sérülés bekövetkezésének reális esélyét hordozza magában (például egy kocsmá-

6 Vajda Márk: Rendészeti kárhely - az életmentés fehér foltja. In: Gaál Gyula - Hautzinger Zoltán (szerk.): i. m. 468. o.

7 Finszter Géza: A változó rendészet és rendészettudomány. In: Gaál Gyula - Hautzinger Zoltán (szerk.): i. m. 5. o.

8 Szabó Andrea: Rendészeti kontroll a Nemzeti Adó- és Vámhivatalnál. Magyar Rendészet, 2013/2., 97. o. 
ban tartózkodó sérült ellátása, ahol rajta kívül többen erősen ittasak, s bármikor agresszívvá válhatnak; tömeg-, illetve sportrendezvényen kialakuló tömeges rendbontás; vagy a forgalmas autópályán, ahol a forgalom korlátozása nélkül a segítséget nyújtó szakképzett ellátók élete, testi épsége is veszélybe kerülhet). A rendészeti kárhely definíciójában az ellenséges emberi magatartás tehát egy konkrét veszélyként értelmezhetö, amely elegendő indokot szolgáltat ahhoz, hogy az a rendészeti szerv által gyakorolt kontroll alkalmazását megkövetelje, de nem vezet a sérülés szükségszerü bekövetkezéséhez.

A rendészeti kárhely másik fontos jellemzője a területi variabilitás és heterogenitás.

\section{Területi variabilitás}

A területi variabilitás azt jelenti, hogy a rendészeti kárhely területi elhelyezkedése nem szükségszerüen statikus. Az intézkedési szituáció változásával elképzelhető, hogy a biztonság érdekében az előzőleg kijelölt terület határait az idő múlásával változtatni kell (például a fegyveres elkövető mozgása befolyásolja a rendészeti kárhely határait).

\section{Területi heterogenitás}

A terület heterogenitása pedig arra utal, hogy a rendészeti kárhely határainak kijelölésekor szükség esetén - a jogszabályok és a rendészeti szakma elöírásainak figyelembevételével - különböző zónák határozhatók meg, amelyekben más-más mértékben korlátozható a személyek mozgása. A heterogenitás egy alkalmazási formájának tekinthető a következőkben bemutatott „négyszintü (négyzónás) rendészeti kárhely" (ábra).

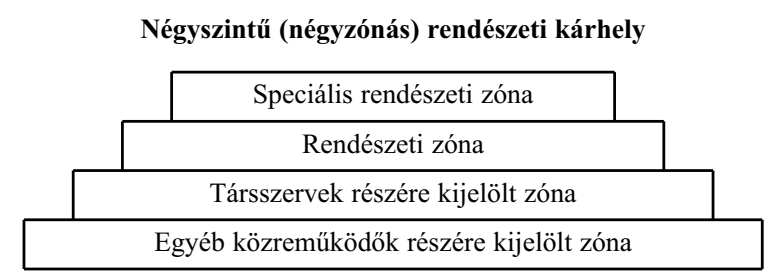

A speciális rendészeti zóna az a terület, ahol a rendészeti feladat sajátosságai, illetve a jogszabályok által meghatározott különös illetékességi szabályok következtében kizárólag különös szakismerettel, képzettséggel és felszerelés- 
sel felvértezett egységek, személyek tartózkodhatnak (például veszélyes, illetve fegyveres elkövető elfogására jogosult szervezeti egység: Terrorelhárítási Központ, Nemzeti Adó- és Vámhivatal Bevetési Igazgatósága); robbanószer felkutatására, hatástalanítására kiképzett egység.

A rendészeti zóna az a terület, ahol az eljárni jogosult és kötelezett rendészeti szerv hivatásos állományú tagjai tartózkodhatnak (például a rendőrség közrendvédelmi, közlekedési állománya, Nemzeti Adó- és Vámhivatal járőr állománya).

A társszervek részére kijelölt zóna az, ahol a káresemények enyhítésében közremüködő társszervek tagjai tartózkodhatnak (például az Országos Mentőszolgálat vagy az elektromos művek munkatársai).

Az egyéb közremüködők részére kijelölt zónában az adott üggyel érintettek közül azok tartózkodhatnak, akiknek a jelenléte elengedhetetlen, de tevőlegesen nem vesznek részt sem a rendészeti, sem pedig az egyéb kárenyhítési munkában (például nélkülözhetetlen tanúk, egy túszhelyzet esetén valamely hozzátartozó).

Természetesen a heterogenitás kapcsán nem minden esetben szükséges az effajta területi felosztás. Az intézkedési szituációtól és körülménytől függően lehetséges, hogy csak két zóna (például a rendészeti és a társszervek részére kialakított) kijelölésére van szükség.

A rendészeti kárhely kereteinek kijelölése, ahogy arra a definíció is utal, , $a z$ eljárni jogosult rendészeti szerv tagja által " történik. A jogosultság kérdése az adott helyzet, illetve az azzal szorosan összefüggő rendészetszakmai és jogi normákban szabályozott elöírások által determinált. Tehát az, hogy a rendészeti kárhely határainak kijelölésére mely szerv és annak milyen szintű tagja jogosult, az az adott szituációt jellemző körülmények összessége figyelembevételével, a szakmai és jogszabályi előírásokra tekintettel határozható meg pontosan. E kérdés összetettsége okán jelen tanulmányomban nem vállalkozom részletes vizsgálatára, az általános és speciális szabályok ismertetésére.

Az eddig leírtak azonban nem adnak feltétlen és egyértelmű magyarázatot arra, hogy miért kell specializálni e területet, mintegy kikényszeríteni a rendészet és egészségügy tudományának összemosását, $\mathrm{s}$ hogy a rendészeti tevékenységgel párhuzamosan miért nem folyhat az adott területen egészségügyi szakellátás.

E kérdésekre a válasz több különböző szakterületi jogszabály együttes értelmezésével adható meg.

Először is fontos tudni, hogy a hatályos magyar jog előírásai értelmében Magyarország területén mindenkit megillet a mentés igénybevételének joga, 
állampolgárságra vagy egészségbiztosítási jogviszony fennállására tekintet nélkül. ${ }^{9}$ A mentés olyan állami feladat, amelyet az Országos Mentőszolgálat, illetve mentési engedéllyel felruházott szervezetek útján gyakorol.

A mentéseket igénylő káresetek jelentős részénél - bár a jogszabály kötelezése okán szükség van a rendészeti jelenlétre, tevékenységre - a kárhelyen felvetődő veszélyforrások szakképzett beavatkozással, a rendészeti szervek aktív közremüködése nélkül is felszámolhatók (például közlekedési baleset roncsának, vasúti vezetékeknek az áramtalanítása; gázszivárgás elhárítása). Így a mentés a veszélyforrás elhárításával biztonságosan végrehajtható.

A rendészeti kárhely esetében ugyanakkor a mentést akadályozó körülmény kizárólag az állami legitim erőszak szerveinek aktív közremüködésével szüntethető meg (például fegyveres személy aktív magatartása). Ilyenek különösen a büncselekmények és balesetek helyszínei, ahol továbbra is fennáll olyan emberi tényező, amely a mentést, illetve az abban részt vevőket veszélyeztetheti.

Ezért a rendészeti szervek tagjai jogosultak a rendészeti feladatokkal érintett terület lezárására azokban az esetekben, amikor személy-, illetve vagyonbiztonságot fenyegető állapot áll fenn. A rendőrségről szóló törvény szerint a rendőr az érintett terület kapcsán ,,megakadályozhatja, hogy oda bárki belépjen vagy onnan távozzék, illetöleg az ott tartózkodókat távozásra kötelezhe$t i{ }^{\prime \prime}{ }^{\prime 0}$. Hasonlóan rendelkezik a pénzügyörök tekintetében a Nemzeti Adó- és Vámhivatalról szóló 2010. évi CXXII. törvény helyszínbiztosításról szóló $36 / \mathrm{I} \S$-a is. ${ }^{11}$

Az előbbiek tehát legitimálják a rendészeti kárhely kijelölését, azonban továbbra sem adnak választ arra, hogy e területen miért nincs mód az Országos Mentőszolgálat tevékenységére. Erre ugyanis a mentésről szóló 5/2006. (II. 7.) EüM. rendelet $9 / \mathrm{A} \S$-a ad választ. A hivatkozott jogszabályi hely szerint: „, A bejelentés alapján a mentésvezetö, illetve a mentésirányitó, a helyszinen a mentőegység vezetôje felelös a helyszin biztonságának értékeléséért. A helyszinen észleltek alapján a mentöegység vezetöje dönt arról, hogy a mentöegység tagjai életének vagy testi épségének veszélyeztetése nélkül

a) a mentés megkezdhetö-e, vagy

b) a megkezdett ellátás folytatható-e.

9 1997. évi CLIV. törvény $95 . \S$

10 1994. évi XXXIV. törvény 37. § e) pont

11 2010. évi CXXII. törvény 36/I § (1)-(2) bek. 
Amennyiben a helyszinen észleltek alapján megállapitható, hogy a mentőegység tagjai élete vagy testi épsége veszélyben van, vagy a mentésen kivül más szerv segitsége is szükséges, a mentöegység vezetöje dönt

a) az ellátás átmeneti felfüggesztéséröl, illetve

b) a helyszín átmeneti elhagyásáról. ",12

A mentésért felelős szervezet tagjai számára tehát a rendészeti kárhelyeken történő tevékenység a veszélyre tekintettel jogszabály által tilalmazott. Egyrészt azért, mert az ott tapasztalható veszélyforrások elhárítása jelentősen túlmutat a mentőszolgálat képességein, másrészt mert a veszély vállalására a mentőszolgálat tagjai, ellentétben a rendészeti szervek hivatásos állományával, nem kötelezhetők. Hiszen míg utóbbiak a szolgálati jogviszony létesítésekor vállalják, hogy kötelezettségeiket akár az életük kockáztatásával is teljesítik $^{13}$, addig ez előbbiek ilyen vállalást nem tesznek.

Az így keletkező szakmai ürt a következőkben részletezett rendészeti elsősegélynyújtó, illetve a rendészeti elsősegélynyújtás hivatott pótolni és megoldani.

\section{Rendészeti elsősegélynyújtó}

A rendészeti kárhely fogalmával meghatározhatók a rendészeti elsősegélynyújtás szempontjából releváns fizikai tér keretei, egyszersmind utalunk a tevékenységet végzők személyi állományára is. A továbbiakban a rendészeti kárhelyen, illetve egyéb szolgálati helyszíneken egészségügyi szempontból hatékony beavatkozásra alkalmas személyek körét egyértelmüen meghatározó fogalmat tisztázom.

A rendészeti elsősegélynyújtó a rendészeti kárhelyen vagy egyéb helyszínen intézkedésre jogosult és kötelezett rendészeti szerv azon tagja, aki speciális kompetenciák birtokában alkalmas arra, hogy az észlelt egészségügyi káresemények következményeit megakadályozza, enyhítse, illetve gondoskodjék a sérült vagy beteg ember szakszerü kivonásáról a további szakképzett egészségügyi ellátás biztosítása érdekében.

A rendészeti elsősegélynyújtás kapcsán a tevékenységi jogosultak és kötelezettek körét mind ez idáig sehol nem határozták meg egyértelmüen. Ta-

12 5/2006. (II. 7.) EÜM. rendelet 9/A § (1)-(2) bek.

13 2015. évi XLII. törvény 44. § (2) bek. 
nulmányomban azért használom a rendészeti elsősegélynyújtó kifejezést, mert az a későbbiekben nem zárja ki a különböző szintű kompetenciájú ellátók előképzettségük, tudásuk, gyakorlatuk, illetve beavatkozási jogosultságuk alapján történő differenciálását (például alapszintủ rendészet elsősegélynyújtói ismeretekkel felvértezett állomány - első beavatkozó, vagy speciális rendészeti elsősegélynyújtó végzettségü állomány - Police Medic ${ }^{14}$ ).

Az érintett személyi kör mellett szándékosan bővítették ki a tevékenység gyakorlására szánt fizikai tér kereteit. Azaz a rendészeti elsősegélynyújtó feladata, illetve a rá vonatkozó követelmény nem korlátozódik kizárólag a rendészeti kárhelyre. Az elsősegélynyújtásra speciálisan képzett rendészeti szakember e kompetenciáit ugyanis minden esetben köteles érvényesíteni az általa észlelt egészségügyi káreseményekkor mindaddig, amíg a szakképzett egészségügyi ellátás nem elérhető (például járőrtevékenység idején észlelt baleset sérültjének ellátása).

Ennek gyakorlati jelentősége és szükségszerüsége abból az egyszerü okból következik, hogy a rendészeti szervek tagja szolgálati tevékenysége sajátosságai okán (például járőrtevékenység), illetve szervezet humán erőforrás terén meglévő túlsúlya következtében sok esetben korábban kerül kapcsolatba az egészségügyi káreseményekkel, mint a szakellátást nyújtó mentőszolgálat munkatársai.

Az Emberi Erőforrások Minisztériumának 2016-os intézményi és fejezeti kezelésű elöirányzati tervezete 7852-ben állapította meg az Országos Mentöszolgálat teljes létszámát (az adminisztratív munkát végzőkkel együtt). ${ }^{15} \mathrm{~A}$ rendészeti szervek hivatásos állományának létszáma - még a közterületi szolgálatot teljesítők tekintetében is - ennél jóval több, így nagyobb az esélye annak, hogy egy káresemény helyszínére hamarabb érkezik valamely rendészeti szerv tagja, mint a mentőszolgálat valamely egysége.

A rendészeti szakember segítségnyújtói kötelezettsége a következő két normából ered: személyes értékrend, illetve jogszabályi elöírás.

A személyes értékrenden az azoknak az erkölcsi normáknak való megfelelést értem, amelyek kielégítik a segítségnyújtás mint emberbaráti kötelezettségvállalás kívánalmait. Habár e szabályok motiváló ereje a legtöbbek számára elhanyagolhatónak tủnik, ez korántsem fedi a valóságot. A közösség által képviselt és elvárt magatartásformákhoz való alkalmazkodás - konformitás - bizonyos formái jóval intenzívebb érvényesüléshez vezetnek, mint az

14 Erdős Ákos: NAV-Medic - Rendészeti ellátás múltja és jelene. Vám-Zoll, 2015/1., 13. o.

15 Az Emberi Erőforrások Minisztériumának tervezett 2016. évi intézményi és fejezeti kezelésü elöirányzatairól szóló beszámoló. http://www.parlament.hu/irom40/04730/adatok/fejezetek/20.pdf 
írott norma. „A szociálpszichológia rámutatott arra, hogy az emberi együttmüködés legkülönbözöbb fokain megjelenö konformitás azon formája jóval erösebb, amely a csoport más tagjainak megfigyelésén alapszik, mint az, amelyeket pusztán a jutalom reménye vagy a büntetés elkerülése motivál. Aki csak azért tartja meg a társadalom irott normáit, mert fél az abban lefektetett retorzióktól, csupán addig lesz szabálykövetö, amig a büntetés lehetöségének reális esélye fennáll. "'16

Mindezeken túl a közösség tagjai között elvárt segítségnyújtás olyan érték, amelynek elősegítése érdekében a jogalkotó szükségesnek látta a kötelező és szankcionálható jogi normák létrehozását.

Az egészségügyről szóló törvény szerint ,,mindenkinek kötelessége - a töle elvárható módon - segitséget nyújtani és tudomása szerint arra illetékes egészségügyi szolgáltatót értesiteni, amennyiben sürgös szükség vagy veszélyeztetö állapot fennállását észleli, illetve arról tudomást szerez" ${ }^{\prime 17}$. E generális szabályon felül a jogalkotó a rendészeti szervek tagjaira speciális segítségnyújtó követelményeket is telepít.

A legitim állami erőszakot alkalmazó szervek tagjainak egyik legnagyobb felelőssége éppen az, hogy e jogukat a közösség értékrendjének szem előtt tartásával kell hogy gyakorolják. Így aztán mind a rendőrök, mind pedig a

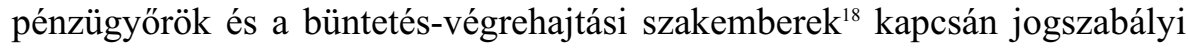
elöírás a segítségnyújtás az intézkedés közben megsérült személyeknek. A különböző szerveket szabályzó normák szövege szerint a hivatásosnak ,,az intézkedés folytán megsérült személy részére - amint ez lehetséges - segitséget kell nyújtani $[\ldots]^{\prime \prime \prime 19}$.

\footnotetext{
16 Erdős Ákos: A kényszermegoldás (?) - A drogtérben alkalmazott kényszerítés, illetve büntető szankciók eredményei, következményei és tanulságai. Szakdolgozat. Semmelweis Egyetem Egészségtudományi Kar, Budapest, 2017, 45-46. o.

17 1997. évi CLIV. törvény, 5. § (3) bek. e) pont

18 A rendészeti elsősegélynyújtás kapcsán szándékosan kerül sor a katasztrófavédelem állományába tartozó hivatásosok megemlítésére. Bár e szervezet felépítése, müködése okán rendkívül szoros kapcsolatban áll a rendészettel, bevonásukat e témába mégsem tartom indokoltnak. Mert, ahogy Finszter Géza is fogalmaz: ,, a katasztrófavédelmi szervezetek a szó közjogi értelmében nem tartoznak a rendészeti igazgatáshoz. A polgári védelem, csakúgy mint a tüzoltóság, nem rendelkezik a rendészetre jellemzó közigazgatási hatósági jogkörökkel, noha általánosabb értelemben vett hatósági jogosultságokat, ha korlátozott mértékben is, az emlitett szervek is gyakorolnak. " Finszter Géza: A rendészeti stratégia alkotmányos alapjai. In: Gaál Gyula - Hautzinger Zoltán (szerk.): Tanulmányok a „Quo vadis rendvédelem? Szabadságjogok, társadalmi kötelezettségek és a biztonság”címủ tudományos konferenciáról. Pécs, 2010, 8. o. [Pécsi Határör Tudományos Közlemények XI.]

19 1994. évi XXXIV. törvény 17. § (2) bek.; 1995. évi CVII. törvény 11. § (5) bek.; 2010. évi CXXII.
} törvény $35 / \mathrm{E} \S(1)$ bek. 
A törvényalkotó szerint a segítségnyújtás kapcsán nem bízhatunk kizárólag az egyén erkölcsi értékeiben, így annak elmulasztását a büntető törvénykönyvben rendeli szankcionálni. E szerint: „,Aki nem nyújt töle elvárható segitséget sérült vagy olyan személynek, akinek az élete vagy testi épsége közvetlen veszélyben van, vétség miatt két évig terjedö szabadságvesztéssel büntetendö. ${ }^{\prime 20}$ Azokban az esetekben, amikor a veszélyhelyzetet az elkövetö idézte elő, vagy a segítségnyújtásra egyébként is köteles, súlyosabb büntetés kiszabását helyezi kilátásba a jogszabály. Ennek pedig nagy jelentősége van a rendészet hivatásos állományú tagjainál tárgyalt speciális segítségnyújtási kötelezettség kapcsán.

Az említett erkölcsi és írott követelmények amellett, hogy súlyos kötelezettségeket rónak a jogalkalmazóra, egyúttal tovább erősítik a rendészeti elsősegélynyújtó személyében rejlő társadalmi értékeket, hiszen kompetenciái birtokában a rendészeti elsősegélynyújtó alkalmas arra, hogy a törvényekben meghatározott „tőle elvárhatóság” és az ,amint ez lehetséges” kívánalmak kapcsán egyaránt kiemelkedőbb szintnek felelhessen meg.

A rendészeti elsősegélynyújtó definíciójának további magyarázata kapcsán fontosnak tartom megjegyezni, hogy a definícióban szereplő speciális kompetenciák nem jelentenek egészségügyi szakképesítést. Az egészségügyről szóló 1997. évi CLIV. törvény szerint ugyanis az egészségügyi szakképesítés ,, az adott egészségügyi tevékenység folytatására jogositó, Magyarországon szerzett, valamint a külföldön szerzett és Magyarországon honositott, illetve elismert, alap-, közép-, emeltszintü, illetve felsöfokú szakképzés vagy felsőoktatási szakképzés keretében megszerzett szakképesités, valamint felsöoktatási alap-, mester-vagy egységes osztatlan képzés keretében megszerzett végzettség és szakképzettség, továbbá egészségügyi szakirányú szakmai képzés, egészségügyi felsőfokú szakirányú szakmai képzés során megszerzett képzettséget" ${ }^{\prime 2 l}$ jelent.

Hazánkban azonban a rendészeti sérült- és betegellátás kapcsán jelenleg még nincs egységesen kidolgozott, hatékonyan müködő, a rendészeti jellegzetességeket is szem előtt tartó, azokat alkalmazó olyan oktatási rendszer, amely megteremtené e területen az egészségügyi szakképzettség megszerzésének lehetőségét.

Bár az orvos- és egészségtudományi képzés területén e kérdés szakmai felkarolására a Semmelweis Egyetem Általános Orvostudományi Kar hon-

20 2012. évi C. törvény 166. § (1) bek.

21 1997. évi CLIV. törvény 1. § q) pont 
véd-, katasztrófa- és rendvédelem-orvostan tanszéke, illetve a Pécsi Tudományegyetem Általános Orvostudományi Kar müveleti medicina tanszékének honvéd-, katasztrófa- és rendvédelem-orvostani tanszéki csoportja kapcsán találunk ígéretes törekvéseket, azonban mind ez idáig ezeken a helyeken sem valósult meg a rendészeti állomány teljes egészére vonatkozó, általánosan elfogadott és alkalmazott képzési rendszer.

A rendészeti elsősegélynyújtó tehát az előbbiekben részletezett képzési kategóriák egyikébe sem sorolható, így nem is minősíthető egészségügyi szempontból szakképzettnek. Mindazonáltal úgy vélem, hogy a rendészeti tevékenység során felvetődő egészségügyi káresemények következményeinek elhárítása, illetve azok mérséklése, megfelelő elsősegélynyújtói kompetenciák birtokában megvalósítható, és nem igényel különösebb szakképzettséget.

A rendészeti elsősegélynyújtók képzésének nem célja más szakismeretet igénylő feladatok átvállalása, jogalkalmazói terminológiával élve: a hatáskör elvonása. A rendészeti elsősegélynyújtó feladata az elsődleges beavatkozás és a rendelkezésére álló lehetőségek birtokában az élet megóvása.

\section{Rendészeti elsősegélynyújtás}

A korábbiakban említett hol?, ki? és mit? kérdések közül az utóbbira adom meg a választ. Hiszen míg a rendészeti kárhely a téma szempontjából jelentős speciális helyet (hol?), a rendészeti elsősegélynyújtó pedig a cselekvők körét (ki?), addig a rendészeti elsősegélynyújtás fogalma magát a gyakorolt tevékenységet jelöli (mit?), ennek révén közvetlenül érzékelhetővé válik a rendészeti szerv közösség iránt fennálló (úgynevezett külső irányú) felelősségvállalásának e speciális formája. ${ }^{22}$

Valószínűleg mindenki számára egyértelmü, hogy az elsősegélynyújtás hasonlóan a kárhelynél tárgyaltakhoz - alapvetően nem a rendészet terminológiájának sajátja. Éppen ezért a fogalom értelmezésében újra célszerü viszszatekinteni a medicinában alkalmazott fogalom magyarázatához. E szerint: „, az elsősegélynyújtás az az egészségügyi beavatkozás, amelyet bárki a végleges szakellátás megkezdése elött végez, baleset vagy hirtelen egészségkárosodás közvetlen körülményeinek elháritása és az állapot további romlásának feltartóztatása érdekében "23.

22 Erdős Ákos: Felelősség a rendvédelemben, múltban és jelenben. Magyar Közigazgatás, 2011/2., 119. o. 23 Hornyák István: Elsősegélynyújtás. Semmelweis Egyetem Egészségtudományi Kar, Budapest, 2008, 17. o. 
A rendészeti elsősegélynyújtás szempontjából e fogalom használata azért tekinthető kifejezetten hasznosnak, mivel az nem ír elő semmilyen, jogszabályban rögzített egészségügyi szakképesítést ${ }^{24}$, ezáltal mindenben összeegyeztethető a rendészeti elsősegélynyújtónál tárgyaltakkal.

Mindazonáltal a rendészeti elsősegélynyújtás több puszta elsősegélynél. S nemcsak azért, mert annak végrehajtója valamely rendészeti szerv hivatásos jogállású tagja, hanem mert a segítségnyújtás e formáját - a rendészeti feladatok sajátosságai miatt - jóval nagyobb komplexitás jellemzi.

Véleményem szerint a rendészeti elsősegélynyújtás a hivatásos szolgálat idején a rendészeti kárhelyen vagy egyéb helyszínen tapasztalt egészségügyi káresemény következményeinek elhárítását, illetve enyhítését szolgáló olyan egészségügyi (elsősegélynyújtó) beavatkozás, amelyet a rendészeti szerv tagja egészségügyi szakképesítés nélkül, az intézkedéstaktikai alapelvek és a jogszabályi kötelezések szem elött tartásával végez.

E megfogalmazás használatát azért tartom előnyösnek, mivel az egyértelmüen utal az elsősegélynyújtó kettős (skizofrén) helyzetére és annak kezelésére. Azaz a rendészeti feladatok mellett megjelenő egészségügyi beavatkozásra és a közöttük fennálló sorrendiségre.

Meggyőződésem, hogy a szolgálatok közben tapasztalt egészségügyi káresemények kapcsán az első beavatkozó számára elsőséget kell hogy élvezzen a rendészeti tevékenység minden olyan sajátos elöírása, amely jogszabályi kötelezés vagy a szükségszerüség okán befolyásolja az ellátás módjának, helyének és idejének megválasztását.

Tehát az ellátás idején és elötte is a rendészeti elsősegélynyújtó (illetve minden társa) folyamatosan szem elött kell hogy tartsa az intézkedést befolyásoló objektív (az intézkedőtől függetlenül létező) és szubjektív (az intézkedőre vonatkozó) releváns tényezőket. ${ }^{25}$ Ha szükséges, ezeknek megfelelöen kell hogy reagáljon, például az olyan intézkedési szituációban, ahol a rendészeti kárhelyen aktív, támadó emberi magatartást tapasztal az intézkedő. Ezekben az esetekben a támadás leküzdése, a támadó kontrollja és felügyelete mint rendészeti feladat elsőséget élvez a helyszínen tapasztalt egészségügyi kárenyhítéshez képest.

E fogalom kapcsán, az egyértelműség érdekében, szükségszerüen fel kell tenni a kérdést, hogy a rendészeti elsösegélynyújtás és a rendészeti sérültellátás között fennáll-e a szinonimitási kapcsolat.

24 1997. évi CLIV. törvény 3. § q) pont

25 11/2008. ORFK utasítás, III. fejezet. 
Véleményem szerint a két kifejezés különböző jelentéstartalmat sugall, ezáltal nem lehetnek egymás szinonimái. Károly Sándor szerint a szinonímia kritériumai a teljes értelemazonosság és a felcserélhetöség. ${ }^{26}$

Azonban meglátásom szerint az elsősegélynyújtás tartalmában szélesebb tevékenységi kört takar, mint a sérültellátás. Utóbbi kifejezés ugyanis indokolatlanul szükíti le a rendészeti elsősegélynyújtó feladatait a sérülések okozta egészségügyi káresemények enyhítésére, míg az előbbi a sérülések mellett számba veszi a különböző betegségek által előidézett akut tünetek egyszerü kezelési módszereinek alkalmazását is (például hipoglikémiás, Grand mal [generalizált tónusos-klónusos roham], eszméletlen légútbiztosítása).

A különbség megértéséhez szükségesnek tartom röviden tisztázni a betegség és sérülés fogalmait, tekintve, hogy e kifejezések elsősorban szintén a medicinában alkalmazottak, így a rendészeti szakemberek nem feltétlenül ismerik a jelentésüket.

A betegség - épp úgy, mint az egészség - a mindenkori orvosi gyakorlat által meghatározott jelenség. ${ }^{27} \mathrm{E}$ fogalom keretei tehát a tudomány fejlődésével elmozdulhatnak, sőt azt az adott közösség és az egyén szubjektív megítélése is befolyásolhatja. Így a betegségek kapcsán az egzakt fogalom megalkotása nem egyszerü feladat.

Thorwald Dethlefsen és Rüdiger Dahlke a következőképp fogalmaz: „, a legkülönbözöbb testmüködések harmonikus összjátéka során jön létre azután az a minta, amelyet egészségnek nevezünk. Ha valamely testfunkció letér a pályáról, ezzel többé-kevésbé ezt a harmóniát veszélyezteti, ezért ilyenkor betegségröl beszélünk. ${ }^{\text {"28 }}$ Cecil G. Helman - utalva a társadalmi szubjektivitásra - pedig azt írja, hogy „, a kulturális tényezők határozzák meg, hogy mely tünetek vagy jegyek" számítanak abnormálisnak, ami segít kialakítani a betegség mintázatát, amelyet „betegségentitásnak” ${ }^{29}$ nevezünk.

John Guyett Scadding viszont az élő szervezetben valamilyen közös jellemző vagy tulajdonság alapján meghatározható „biológiai hátrányok” megjelenését nevezi betegségnek. ${ }^{30}$

\footnotetext{
26 Idézi Andor József: A fogalmi keret, a szómező és a szinonimitás határvonalai. In: Gecső Tamás Spannraft Marcellina (szerk.): A szinonimitásról. Tinta Kiadó, Budapest, 1998, 8. o.

27 Szántó Zsuzsanna: Az egészséggel kapcsolatos életstílus: betegviselkedés és egészségviselkedés. Doktori (PhD) értekezés. Semmelweis Egyetem, Budapest, 2005, 6. o.

28 Thorwald Dethlefsen - Rüdiger Dahlke: Út a teljességhez: A betegség jelentése és jelentősége. Magyar Könyvklub Rt., Budapest, 2000, 7. o.

29 Cecil G. Helman: Kultúra, egészség és betegség. Melánia Kiadó, Budapest, 1998, 102. o.

30 John Guyett Scadding: Health and disease: what can medicine do for philosophy? Journal of Medicalethics, vol. 14, no. 3, 1988, p. 121.
} 
A betegség tehát rendkívül összetett, több tényező által egyszerre befolyásolt fogalom, s jóval több mint az egészség ellenpólusa. Erre utal az Ruth $S$. Downie által idézett 1946-os WHO-meghatározás is, miszerint , az egészség a teljes testi, lelki és szociális jólét állapota, s nem csupán a betegség vagy fogyatékosság hiányát jelenti ${ }^{\prime 3}$.

Összességében azt mondhatjuk, hogy a betegség az egészséges, egyensúlyi állapot felbomlása, károsodása, illetve a szervezet nem megfelelő müködése, amelynek során egy adott testrész, szerv vagy rendszer kóros állapota áll be, aminek számos oka lehet (például fertőzés, genetikai probléma, pszichét ért súlyos terhelés), és ezt jelek vagy tünetek rendkívül széles csoportja jellemzi.

A sérülés ezzel szemben szükségszerüen feltételez egy a szervezetre gyakorolt fizikai (kémiai, például vegyszer okozta felmaródás) behatást. Az 1978. évi IV. törvényhez füzött Kommentár szerint: ,, a testi épség sértése az emberi testre gyakorolt [...] fizikai ráhatással [...] valósitható meg, amely az emberi testen vagy a test szerveiben sérülést okoz. [...] A testi sérülés, mint eredmény a szervezet sejtjeiben, szöveteiben létrejött külsérelmi nyomokkal járó eltérés vagy müködési zavar."

A betegség és a sérülés tehát - ahogy a leírtakból kiderült - nem azonos fogalmak. Mindamellett fontos tudni, hogy egymással rendkívül szoros kapcsolatban állnak, és hatást gyakorolhatnak egymásra. Miképp az idézett Kommentár is megjegyzi, előfordulhat, hogy egy fizikai hatás révén okozott sérülés a későbbiekben krónikus betegség kialakulásához vezet (például koponyasérülés hatására kialakuló elmebetegség vagy epilepszia) ${ }^{33}$, s ugyanez megeshet fordítva is, amikor a betegség tünete idéz elő sérülést (például Grand mal [generalizált tónusos-klónusos roham] során elszenvedett törés, zúzódás).

Úgy vélem, hogy az előbbiek is jól kifejezik, miért tekinthető szélesebb kategóriának az elsősegélynyújtás, mint a sérültellátás. Így a továbbiakban javasolom inkább a rendészeti elsősegélynyújtás kifejezés használatát a rendészeti sérültellátás helyett.

31 Ruth S. Downie: Definition. Journal of Medicalethics, vol. 20, no. 3, 1994, p. 182

$32 \mathrm{Az}$ 1978. évi IV. törvény 170. §-ához füzött részletes kommentár.

33 Uo. 


\section{A rendészeti elsősegélynyújtás általános lényegéről}

A rendészeti elsősegélynyújtás témájában alkotott általános fogalmak joggal kelthetik fel a részleteket bemutató magyarázatok és a gyakorlati megvalósulás bemutatása iránti igényt.

Tekintettel azonban arra, hogy e téma már önmagában jelentős terjedelmü tudományos munka lenne, a következökben csupán azon általánosságok ismertetésére szorítkozom, amelyek a társadalmi, erkölcsi és jogszabályi aspektusokon túl az orvos- és egészségtudomány nézőpontjából is igazolják e téma szakmai jelentőségét.

Az Egészségügyi Világszervezet (WHO) 2010-es beszámolója szerint „,minden egyes nap több mint 15000 ember vesziti életét, valamilyen sérülés következtében. E sérülések okai között szerepelnek az auto-, illetve heteroagressziv cselekmények, a közúti balesetek, az égések, fulladások, magasból esések és a mérgezések. " ${ }^{34}$ Összességében tehát a világon megközelítőleg 5,8 millió ember hal meg sérülések miatt évente. Ez az összhalálozási mutató mintegy tíz százaléka. Többen halnak meg így, mint malária, tuberkulózis és AIDS miatt összesen. ${ }^{35}$ Bár 2014-ben ez a szám valamivel csökkent, továbbra sem távolodott el az ötmilliótól. ${ }^{36}$

Hazánkban a sérülések okozta halálozások értéke megközelíti a világátla-

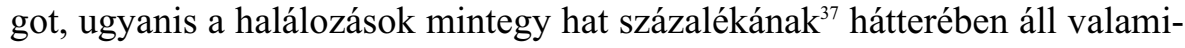
féle sérülés.

Önmagában a sérülések magas számának tényszerüsége azonban a következmények (elhalálozások) tekintetében nem ad teljes választ. A probléma másik - rendkívüli jelentőségü - részére a Márton és Gorove szerzőpáros a következőképp hívja fel a figyelmet: „A magas korai halálozás 50\%-a következik be a helyszinen és 30\%-a a kórházi ellátás elsö 24 órájában. [...] A tapasztalatok szerint a korai halálesetek 48\%-a potenciálisan megelözhetö megfelelö korai légútbiztositással, a kritikus mellkasi sérülés, a külső vérzések, valamint a vérzéses shock adekvát ellátásával. "s8

\footnotetext{
34 Injuries and violence: the facts. World Health Organization, Geneva, 2010, p. 2. http://apps.who.int/iris/bitstream/10665/44288/1/9789241599375_eng.pdf 35 Uo. 
A rendészeti elsősegélynyújtókkal szemben támasztott elsődleges követelmény tehát, hogy az említett sérülések, kórfolyamatok lehetöségek szerinti legteljesebb ellátását hajtsák végre. Így a rendészeti elsősegélynyújtás kompetenciahatárait meglátásom szerint a légútbiztosítás, a (nagy volumenü) vérzéscsillapítás, a súlyos, áthatoló mellkasi sérülések kapcsán felvetődő pneumothorax (PTX) kialakulását ${ }^{39}$, súlyosbodását elkerülő alapszintü ellátás, a testhőmérséklet védelme, az újraélesztés és egyéb elsősegélynyújtói beavatkozások, valamint a szakszerü, egészségügyi szempontból releváns információkat közlő segélykérés, mentőhívás ${ }^{40}$ köré lehet vonni.

Bár utóbbi nem szigorúan az elsősegélynyújtás része, elengedhetetlen a rendészeti elsősegélynyújtó esetében. A mentésről szóló rendelet értelmében ugyanis a mentésirányító a bejelentés tartalma és az összes körülmény értékelése alapján dönt a mentés szükségességéröl, továbbá intézkedik a megfelelő szintü mentőegység, illetve az egyéb szakszervek riasztásáról. ${ }^{41}$ A szakszerü tájékoztatás által elérhető, hogy a káresemények helyszínére idejében érkezhessen a valós igényeknek megfelelő mentőegység.

\section{Összegzés}

Nem lehet elégszer hangsúlyozni, hogy a rendészeti elsősegélynyújtás egy a rendészeti intézkedéstaktikába integrált, a jogszabálynak megfelelö egészségügyi szakképesítést nem igénylő, egészségügyi beavatkozási forma.

A rendészeti munka müvelöitől alapszinten azonban elvárható, hogy az egészségügyi káreseményekre azonnal képesek legyenek reagálni, s azok enyhítése érdekében megtegyék a legelső lépéseket (például kezdjék meg az újraélesztést). Ezek az ismeretek - magabiztos rendészetszakmai tudás birtokában - könnyen elsajátíthatók, és a képzési rendszerben fejleszthetők.

Ennek megfelelően fontos lehet annak a vizsgálata, hogy e speciális kompetenciák megszerzését lehetővé tevő oktatási rendszerben miként jelenik meg az egészségügyi szakismeret mellett a rendészeti tevékenység alapjait adó intézkedéstaktika.

\footnotetext{
39 „A pneumothorax a levegőnek a mellhártyaüregben történő megjelenésével definiálható.” Marc Noppen - Tom de Keukeleire: Pneumothorax. Respiration, vol. 76, 2008, p. 121.

40 Hunka Balázs - Kisiván Csaba: Az elsősegélynyújtás kézikönyve. Medicina Kiadó, Budapest, 2015, 14. o.

41 5/2006. (II. 7.) EÜM. rendelet 4. § (2) bek.
} 
Az ez irányú képzésben megfelelő formában és mértékben szükséges a különböző tudomány- és szakterületek összehangolása, bevonása, ez lehetővé teszi, hogy a rendészeti elsősegélynyújtó mindenkor a lehető legmagasabb színvonalon legyen képes segíteni az állampolgárokon, társain és adott esetben önmagán.

Véleményem szerint az előbbiekben részletezett kompetenciák alapjai megfelelő támogatottság és szervezés mellett a rendészeti alapképzések minden formájában (tisztképzés, tiszthelyettes-képzés) megszerezhetők, elsajátíthatók.

A társadalom és a tudomány fejlődése is érezhető módon arra sarkallja a rendészetet, valamint annak szakmai képviselöit, müvelöit, hogy kövessék e progresszív folyamatokat.

Az Európai Unió vámügyi kompetencia-keretrendszere például, amelynek kidolgozására a vámigazgatások teljesítményének javítása, növelése, folyamatosan változó környezethez való alkalmazkodásának elősegítése, illetve a megfelelő munkaerő biztosítása érdekében került sor ${ }^{42}$, az alapvető értékek között megköveteli a vámigazgatások alkalmazottaitól, hogy a folyamatos tanulás és szakmai fejlődés jegyében elkötelezettek legyenek saját képességeik fejlesztése mellett, és nyitottan álljanak az életen át tartó tanuláshoz. ${ }^{43}$

S ugyanez a követelmény a rendörség kötelékében is. Ahogyan Gecse Gábor és Volter Zsolt a munka minősége kapcsán támasztott elvárásként megjegyzi: „A rendőr jól ismeri a tevékenységét szabályozó elöirásokat, munkáját lelkiismeretesen, magas színvonalon, törvényesen, s szakszerüen végzi. Böviti szakmai ismereteit, fejleszti képességeit. "'

A rendészeti szervek részére felkészített hallgatói állomány (illetve a már hivatásos jogviszonyban állók) ez irányú képzése nem csupán kívánatos, hanem társadalmilag elvárt. A modern rendészet szellemiségében, kompetenciáiban jócskán túlmutat a legitim erőszak alkalmazásán. Napjaink rendészetének a jelenlétben realizálódó funkciója ${ }^{45}$, illetve a közösség szolgálata kapcsán tá-

42 Magasvári Adrienn: Pénzügyőrt keresünk... De milyen legyen? Az EU vámügyi kompetencia-keretrendszere. Magyar Rendészet, 2016/3., 148. o.

43 European Commission Taxation and Customs Union: Az EU vámügyi kompetencia keretrendszere Kompetencia szótár, 2014. www.circabc.europa.eu/faces/jsp/extension/wai/navigation/container.jsp

44 Gecse Gábor - Volter Zsolt: A rendőri hivatás etikai kódexe. In: Gaál Gyula - Hautzinger Zoltán (szerk.): Tanulmányok „A rendészet kultúrája - kulturált rendészet” című tudományos konferenciáról. Pécs, 2009, 88. o. [Pécsi Határőr Tudományos Közlemények X.]

45 A modern rendőrség (esetünkben kiterjesztve ezt az egész rendészetre) funkciói: a jelenlét, az információszerzés és a törvényes erőszak alkalmazása. Kozáry Andrea: Nemzetközi összehasonlító szervezettan. Rendőrtiszti Föiskola, Budapest, 2008, 36-37. o. 
masztott követelmények magukban foglalják azt a társadalmi igényt, miszerint az egyenruhás a káresemények észlelésekor lelkiismeretesen cselekedjék. Ahogy Max Brooks megfogalmazta: ,egyenruhában is az a kötelességünk, hogy a lelkiismeretünket szolgáljuk, bármi áron"*46.

\section{IRODALOM}

Andor József: A fogalmi keret, a szómező és a szinonimitás határvonalai. In: Gecső Tamás Spannraft Marcellina (szerk.): A szinonimitásról. Tinta Kiadó, Budapest, 1998, 7-19. o.

Brooks, Max: World War Z. Könyvmolyképző Kiadó, Szeged, 2013

Czuczor Gergely - Fogarasi János: A magyar nyelv szótára. Emich Gusztáv Magyar Akadémiai Nyomdász, Pest, 1862

Dethlefsen, Thorwald - Dahlke, Rüdiger: Út a teljességhez: A betegség jelentése és jelentősége. Magyar Könyvklub Rt., Budapest, 2000

Downie, Ruth S.: Definition. Journal of Medicalethics, vol. 20, no. 3, 1994

Egészségügyi alapismeretek, elsősegélynyújtás a harctéri életmentő katonák részére. tansegédlet. MH Egészségügyi Központ Egészségügyi Főnökség, Budapest, 2013

Erdős Ákos: A kényszermegoldás (?) - A drogtérben alkalmazott kényszerítés, illetve büntető szankciók eredményei, következményei és tanulságai. Szakdolgozat. Semmelweis Egyetem Egészségtudományi Kar, Budapest, 2017

Erdős Ákos: Felelősség a rendvédelemben, múltban és jelenben. Magyar Közigazgatás, 2011/2.

Erdős Ákos: NAV-Medic - Rendészeti ellátás múltja és jelene. Vám-Zoll, 2015/1.

European Association for Injury Prevention and Safety Promotion, 2013, p. 8.

Fenyvesi Csaba: A kriminalisztika alapkérdései. In: Gaál Gyula - Hautzinger Zoltán (szerk.): Tanulmányok „A változó rendészet aktuális kihívásai” című tudományos konferenciáról. Pécs, 2013, 341-350. o. [Pécsi Határőr Tudományos Közlemények XIV.]

Finszter Géza: A rendészeti stratégia alkotmányos alapjai. In: Gaál Gyula - Hautzinger Zoltán (szerk.): Tanulmányok a „Quo vadis rendvédelem? Szabadságjogok, társadalmi kötelezettségek és a biztonság” című tudományos konferenciáról. Pécs, 2010, 5-24. o. [Pécsi Határör Tudományos Közlemények XI.]

Finszter Géza: A változó rendészet és rendészettudomány. In: Gaál Gyula - Hautzinger Zoltán (szerk.): „A változó rendészet aktuális kihívásai” címü tudományos konferenciáról, Pécs, 2013, 5-12. o. [Pécsi Határőr Tudományos Közlemények XIV.]

Gecse Gábor - Volter Zsolt: A rendőri hivatás etikai kódexe. In: Gaál Gyula - Hautzinger Zoltán (szerk.): Tanulmányok „A rendészet kultúrája - kulturált rendészet” című tudományos konferenciáról. Pécs, 2009, 79-92. o. [Pécsi Határőr Tudományos Közlemények X.]

Gőbl Gábor: Oxiológia. Medicina Könyvkiadó Zrt., Budapest, 2006

Helman, Cecil G.: Kultúra, egészség és betegség. Melánia Kiadó, Budapest, 1998

46 Max Brooks: World War Z. Könyvmolyképző Kiadó, Szeged, 2013, 138. o. 
Hornyák István: Elsősegélynyújtás. Semmelweis Egyetem Egészségtudományi Kar, Budapest, 2008

Hou, Chen - Gheorghiu, Stefan - Huxley, Virginia H. - Pfeifer, Peter: Reverse engineering of oxygen transport in the lung: Adaptation to changing demands and resources through space-filling networks. PLOS Computational Biology, vol. 6, no. 8, 2010

Hunka Balázs - Kisiván Csaba: Az elsősegélynyújtás kézikönyve. Medicina Kiadó, Budapest, 2015

Injuries and violence: the facts. World Health Organization, Geneva, 2010

Józsa Rita - Atlasz Tamás - Tékus Éva - Wilhelm Márta: A terhelésélettan alapjai I. Pécsi Tudományegyetem, Pécs, 2015

Kozáry Andrea: Nemzetközi összehasonlító szervezettan. Rendőrtiszti Főiskola, Budapest, 2008

Kragh, John F. - Walters, Thomas J. - Baer, David G. - Fox, Charles J. - Wade, Charles E. - Salinas, Jose - Holcomb, John B.: Survival with emergency Tourniquet use to stop bleeding in major limb trauma. Annals of Surgery, vol. 249, no. 1, 2009

Leech, Caroline - Porter, Keith - Steyn, Richard - Laird, Colville - Virgo, Imogen Bowman, Richard - Cooper, David: The pre-hospital management of life-threatening chest injuries: A consensus statement from the Faculty of Pre-Hospital Care, SAGE Journals, vol. 19, no. 1,2017

Magasvári Adrienn: Pénzügyőrt keresünk... De milyen legyen? Az EU vámügyi kompetencia-keretrendszere. Magyar Rendészet, 2016/3.

Márton Erzsébet - Gorove László: A súlyos sérült kórházon kívüli ellátása. Módszertani útmutató. Országos Mentőszolgálat, Budapest, 2010

Noppen, Marc - Keukeleire, Tom de: Pneumothorax. Respiration, vol. 76, 2008

Pap Zoltán: Közúti elsősegélynyújtás. Műszaki Könyvkiadó, Budapest, 1984

Pápai Tibor: Az egészségügyi tisztek és altisztek katona-egészségügyi ismeretei, kompetenciái, azok fejlesztésének lehetőségei. Doktori $(\mathrm{PhD})$ értekezés. Nemzeti Közszolgálati Egyetem, Budapest, 2013

Scadding, John Guyett: Health and disease: what can medicine do for philosophy? Journal of Medicalethics, vol. 14, no. 3, 1988

Seres Ambrusné: Betegvizsgálat, a sérült állapotának értékelése, segélyhívás, a beteg szállítása. Nemzeti Szakképzési és Felnőttképzési Intézet, Budapest, 2008

Szabó Andrea: Rendészeti kontroll a Nemzeti Adó- és Vámhivatalnál. Magyar Rendészet, 2013/2.

Szántó Zsuzsanna: Az egészséggel kapcsolatos életstílus: betegviselkedés és egészségviselkedés. Doktori (PhD) értekezés. Semmelweis Egyetem, Budapest, 2005

Szent-Györgyi Albert: Az élő állapot. Kriterion Könyvkiadó, Bukarest, 1973

Vajda Márk: Rendészeti kárhely - az életmentés fehér foltja. In: Gaál Gyula - Hautzinger Zoltán (szerk.): Tanulmányok „A változó rendészet aktuális kihívásai” című tudományos konferenciáról, Pécs, 2013, 467-469. o. [Pécsi Határőr Tudományos Közlemények XIV.] 


\section{JOGSZABÁLYOK}

Magyarország Alaptörvénye

1978. évi IV. törvény a Büntető Törvénykönyvröl

1994. évi XXXIV. törvény a rendörségröl

1995. évi CVII. törvény a büntetés-végrehajtási szervezetről

1997. évi CLIV. törvény az egészségügyröl

2010. évi CXXII. törvény a Nemzeti Adó- és Vámhivatalról

2015. évi XLII. törvény a rendvédelmi feladatokat ellátó szervek hivatásos állományának szolgálati jogviszonyáról

5/2006. (II. 7.) EÜM rendelet a mentésröl

11/2008. sz. ORFK utasítás a rendőri intézkedések gyakorlati végrehajtásának alapvető taktikáiról

5/2014. (II. 27.) BM OKF utasítás a tủzoltás-taktikai szabályzat kiadásáról 